\title{
Mengurangi Kenakalan Remaja Menggunakan Konseling Behavioral pada Peserta Didik di SMA
}

\author{
Muhammad Arief Maulana, Panggih Wahyu Nugroho
}

Universitas Veteran Bangun Nusantara

maulgonzales89@gmail.com

Submitted: 2019-03-17, revised : 2019-03-17, accepted : 2019-06-25

\begin{abstract}
: juvenile delinquency is indeed a phenomenon that occurs at the developmental stage of adolescence. Phenomena that occur are behaviors that deviate from the norms that apply in the community such as ditching, bullying, smoking, drinking liquor, lying, and others. All behaviors carried out bby adolescents on the basis of wanting to try and be dominantly influenced by environmental factors. Juvenile delinquency reflects adolescents having difficulty finding their identity so that they experience an identity crisis. Researchers want to reduce juvenile delinquency using behavioral counseling approaches. The reason for using this counseling is because behavioral counseling is counseling which is a combination of approaches in cognitive psychotherapy therapy and behavior therapy. The type of research used is using experimental research. The design of the research in this study used was the prettest and post-test group. The pre-test results showed that students got ajuvenile delinquency score of $54.23 \%$ in the medium criteria, while the post test showed a score of 32.08 in low criteria. Based on the results of the calculation of the comparison of the pre-test and post-test scores, the average respondents experienced a decrease in juvenile delinquency by $22.15 \%$. This proves that behavioral counseling can reduce the level of juvenile delinquency. While the wilcoxon test obtained $z$ count of -1.82 , because this value is an absolute value so that the negative sign is not taken into account. So that the calculated $z$ value becomes 1.82, then the calculated $z$ value is compared with the $z$ table value with an error level of 0.05. The conclusion is that the juvenile delinquency of sma $n 1$ nguter can be reduced through counseling behavioral approaches.
\end{abstract}

Keywords: juvenile delinquency; behavioral counseling

\begin{abstract}
Abstrak: kenakalan remaja memang sebuah fenomena yang terjadi di tahap perkembangan masa remaja. Fenomena yang terjadi merupakan perilaku yang menyimpang dari norma yang berlaku dimasyarakat misalnya membolos, bullying, merokok, minum minuman keras, berbohong, dan lain-lain. Semua perilaku dilakukan oleh remaja atas dasar ingin coba-coba dan sanga dominan dipengaruhi oleh faktor lingkungan. Kenakalan remaja mencerminkan remaja kesulitan untuk menemukan identitas diri sehingga mengalami krisis identitas. Peneliti ingin mengurangi kenakalan remaja menggunakan pendekatan konseling behavioral. Alasan penggunaan konseling ini adalah karena konseling behavioral adalah konseling yang merupakan perpaduan antara pendekatan dalam psikoterapi cognitive therapy dan behaviour therapy. Jenis penelitian yang digunakan adalah dengan menggunakan penelitian eksperimen. Design penelitian dalam penelitian ini yang digunakan adalah pretest dan post test group. Hasil pre test menunjukkan bahwa siswa mendapatkan skor kenakalan remaja sebesar $54,23 \%$ dalam kriteria sedang, sedangkan post tes menunjukkan skor 32,08 dalam kriteria rendah. Berdasarkan hasil perhitungan perandingan skor pre-test dan post test, rata-rata responden mengalami penurunan kenakalan remaja sebesar $22,15 \%$. Hal ini membuktikan bahwa konseling behavioral dapat mengurangi tingkat kenakalan remaja. Sedangkan uji wilcoxon diperoleh z hitung sebesar -1.82 , karena nilai ini adalah nilai mutlak sehingga tanda negatif tidak diperhitungkan. Sehingga nilai $\mathrm{z}$ hitung menjadi 1.82 , selanjutnya nilai $\mathrm{z}$ hitung ini dibandingkan dengan nilai $\mathrm{z}$ tabel dengan taraf kesalahan 0.05. Simpulannya adalah kenakalan remaja sma $\mathrm{n} 1$ nguter dapat dikurangi melalui konseling pendekatan behavioral.
\end{abstract}

Kata kunci: kenakalan remaja; konseling behavioral

\section{Pendahuluan}

Era digitalisasi sekarang ini sangat berdampak kepada berbagai aspek dalam kehidupan, salah satunya adalah perilaku. Perilaku manusia cenderung dipengaruhi adanya keinginan untuk mengidentifikasi atau meniru apa yang dilihatnya. Permasalahan muncul bilamana tayangan atau sesuatu yang dilihatnya adalah sesuatu yang tidak pantas atau tidak sesuai dengan fase perkembangannya. Contoh seorang remaja melakukan hubungan seksual diluar nikah hingga hamil dan terjadi upaya pembunuhan. Seperti peristiwa yang dikutip dari 
harian tribun Jogja, pada tahun 2018, di Banyumas seorang siswi SMA berinisial NM hamil diluar nikah, kemudian berupaya untuk membunuh bayinya dengan gunting di kamar mandi rumah sakit. Peristiwa di media merdeka.com tahun 2018, seorang remaja yang kalah judi tega mencuri barang milik tetangga dan membunuhnya yang terjadi di Boyolali. Kenakalan remaja ini cenderung mengarah ke tindak kriminalitas dan memaksa remaja berhadapan dengan hukum. Perilaku yang seharusnya tidak layak dilakukan oleh anak remaja, sekarang ini justru sering dilakukan oleh remaja. Pergeseran tingkat kenakalan remaja menuju tindak pidana dewasa ini sering terliput oleh media. Kenakalan remaja memang sebuah fenomena yang terjadi di tahap perkembangan masa remaja. Fenomena yang terjadi merupakan perilaku yang menyimpang dari norma yang berlaku dimasyarakat misalnya membolos, bullying, merokok, minum minuman keras, berbohong, dan lain-lain. Semua perilaku dilakukan oleh remaja atas dasar ingin coba-coba dan sanga dominan dipengaruhi oleh faktor lingkungan.

Remaja diharapkan mampu untuk mengembangkan kemampuan dan menemukan jati diri melalui kegiatan-kegiatan yang positif. Masa remaja merupakan masa emas untuk membentuk suatu kepribadian individu yang mempengaruhi masa dewasa nantinya. Seorang remaja belajar untuk menemukan identas diri yang membedakan satu individu dengan individu lainnya, mencoba untuk mengambil peran orang dewasa sebagai bentuk perkembangan diri. Namun seringkali keinginan untuk menjadi dewasa dan menemukan identitas diri tidak berlangsung lancar, melainkan sering terjadi penyimpangan dan kegagalan sehingga menimbulkan permasalahan.

Stanley (dalam santrock, 2002) menyatakan bahwa masa remaja penuh dengan pergolakan dan konflik serta buaian suasana hati. Karena remaja menganggap dirinya sudah mampu mandiri, dan berkeinginan untuk memecahkan masalahnya sendiri sesuai dengan keyakinan diri dan menolak bantuan orang lain. Masa remaja penuh dengan energi dan semangat untuk menuju kedewasaan, yang mejadi persoalan adalah bagaimana seorang remaja ini menyalurkan energi dan semangatnya untuk sesuatu hal yang positif.

Kenakalan remaja salah satu bentuk peristiwa dimana periode remaja tidak digunakan sebaik mungkin untuk mendukung pencarian identitas diri melalui hal yang positif. Perilaku yang beresiko menimbulkan masalah yang mampu menghambat perkembangan kedewasaan sering dialami remaja. Kenakalan remaja mencerminkan remaja kesulitan untuk menemukan identitas diri sehingga mengalami krisis identitas. Erickson dalam yusuf (dalam Yusuf, 2016) menyatakan bahwa tugas utama remaja adalah keluar dari krisis identitas untuk dapt menjadi orang dewasa yang memahami dirinya secara utuh dan memahami peranannya di masyarakat.

Krisis identitas menjadi tantangan remaja untuk diselesaikan, remaja dikatakan mampu keluar dari identitas bila mampu menyelesaikan tiga perkara yaitu pilihan pekerjaan, adopsi nilai yang diyakini, perkembangan identitas seksual yang memuaskan. Remaja sudah mampu menemukan identitas diri bila remaja mampu memiliki pemahaman dan beradaptasi terhadap dirinya dan peranannya di masyarakat.

Siswa SMA pada umumnya berusia antara 16 sampai 19 tahun, usia tersebut masuk dalam kategori remaja. Batas usia remaja adalah rentang usia 13-21 tahun yang terbagi mejadi remaja awal (13-17 tahun), dan remaja akhir (18-21 tahun)(Hurlock, 2002). Mayoritas kenakalan remaja terjadi pada remaja dibawah usia 21 tahun, dan angka tertinggi tingkat kenakalan remaja pada usia 15-18 tahun. Pada usia tersebut remaja masih duduk di sekolah menengah pertama atau atas. Dengan kata lain, siswa SMP/SMA sering melakukan penimpangan perilaku baik saat berada di sekolah maupu di lingkungan masyarakat(Kartono, 1992).

Peneliti ingin mengurangi kenakalan remaja menggunakan pendekatan konseling behavioral. Alasan penggunaan konseling ini adalah karena konseling behavioral adalah konseling yang merupakan perpaduan antara pendekatan dalam psikoterapi cognitive therapy dan behaviour therapy. Terapi kognitif berfokus pada pikiran, memfasilitasi individu belajar 
mengenali dan mengubah cara berfikir agar menjadi lebih terarah. Sementara terapi tingkah laku arahnya membangun hubungan antara situasi permasalahan dengan kebiasaan-kebiasaan mereaksi masalah. Individu belajar mengubah perilaku, menenangkan pikiran dan tubuh hingga merasa lebih baik, berpikir lebih realistik dan membantu memilih keputusan yang tepat (Corey, 2013a). Intinya konseling behavioral merupakan konseling yang berfokus pada perubahan perilaku. Jadi dalam penelitian ini diharapkan kenakalan remaja siswa sma dapat dikurangi. Tujuan penelitian ini untuk mengetahui bahwa kenakalan remaja dapat dikurangi dengan layanan konseling behavioral. Hipotesis penelitian ini yaitu konseling behavioral mampu mengurangi tingkat kenakalan remaja (juneville deliquency) siswa SMA N 1 Nguter.

Kenakalan remaja atau dalam bahasa inggris dikenal dengan istilah juvenile delinquency merupakan gejala patologis sosial pada remaja yang disebabkan oleh satu bentuk pengabaian sosial. Akibatnya, mereka mengembangkan bentuk perilaku yang menyimpang(Kartono, 1992). Kenakalan remaja didefinisikan sebagai suatu perilaku yang dilakukan oleh remaja dengan mengabaikan nilai-nilai sosial yang berlaku dimasyarakat. Kenakalan remaja merupakan kecenderungan melakukan tindakan pelanggaran norma yang dilakukan oleh remaja yang dapat menghambat perkembangan dirinya dan merugikan orang lain(Sumiati, Nurhaeni, \& Aryani, 2009).

Bentuk kenakalan remaja menjadi empat yaitu: kenakalan remaja terisolir, kenakalan remaja neurotik, kenakalan remaja psikotik, kenakalan remaja defek moral(Kartono, 1992). Penelitian ini bentuk kenakalan remaja yang akan diteliti merupakan kenakalan remaja terisolir, karena fenomena yang sering terjadi di sekolah. Kenakalan yang relatif dalam kategori ringan atau sedang misalnya perilaku merokok, membolos, melakukan bullying, geng motor, dan lain-lain. Faktor yang mempengaruhi kenakalan remaja diantaranya: perselisihan atau konflik orang tua maupun anggota keluarga, perceraian, sikap perlakuan orang tua yang buruk terhadap anak, penjualan alat-alat kontrasepsi yang kurang terkontrol, hidup menganggur, kurang dapat memanfaatkan waktu luang, pergaulan negatif, beredarnya film bajakan dan bacaan porno, kehidupan moralitas masyarakat yang tidak baik, diperjual belikannya miras dan obat terlarang, kehidupan ekonomi keluarga yang kurang(Yusuf, 2016).

Konseling behavioral adalah konseling yang berfokus pada perubahan perilaku (Latipun, 2014). Konseling behavioral adalah "konseling yang diharapkan untuk menghasilkan perubahan yang nyata dalam perilaku konseli (counsele behavioral)"(Winkel \& Hastuti, 2005). Terapi tingkah laku adalah penerapan aneka raga, teknik dan prosedur yang berakar pada berbagai teori tentang belajar(Corey, 2013b). Terapi ini menyertakan penerapan yang sistematis prinsip-prinsip belajar pada pengubahan tingkah laku ke arah cara-cara yang lebih adaptif". Alasan penggunaan konseling ini adalah dengan menggunakan konseling behavioral, akan mempengaruhi pola pikir siswa untuk tidak melakukan perilaku yang menghambat proses belajar di kelas. Perilaku itu akan merugikan diri dan juga orang lain. Jika pola pikir siswa dapat diubah untuk tidak melakukan perilaku kenakalan remaja, selanjutnya akan berpengaruh kepada perilaku siswa untuk melakukan tindakan yang mendukung proses belajar mengajar.

Karakteristik konseling behavioral adalah pemusatan perhatian apada tingkah laku yang tampak dan spesifik, kecermatan dan penguraian tujuan-tujuan treatment, perumusan prosedur treatment yang spesifik yang sesuai dengan masalah, penafsiran obyektif atas hasilhasil terapi. Maka pemilihan konseling behavioral sangat tepat dan sesuai dengan perilaku kenakalan remaja yang sering dilakukan oleh siswa Sekolah Menengah Atas (Corey, 2013b).

\section{Metode Penelitian}

Jenis penelitian yang digunakan adalah dengan menggunakan penelitian eksperimen. Penelitian ini sengaja memberikan perlakuan sehingga menimbulkan sesuatu kejadian atau keadaan, kemudian diteliti bagaimana akibatnya. Dalam hal ini peneliti ingin mengurangi 
kenakalan remaja melalui layanan konseling behavioral, kemudian peneliti ingin mengetahui bagaimana penurunan tingkan kenakalan remaja setelah diberikan perlakuan. Desain penelitian dalam penelitian ini yang digunakan adalah pre test dan post test group. Variabel terikat yaitu kenakalan remaja, sednagka variabel bebas yaitu konseling behavioral. Rancangan penelitian sesuai dengan tahapan konseling behavioral yaitu melalui tahap asesment, goal setting, technique implementation, evaluaition-termination dan terakhir feed back. Alasan peneliti merujuk apada langkah-langkah tersebut adalah dianggap paling runtut dan mudah untuk dilaksanakan. Konseling dilakukan sebanyak 2 kali di masing-masing konseli dengan mengimplementasikan teknik kontrak perilaku sebagai bentuk komitmen konseli untuk merubah perilakunya.

Populasi yang dimaksudkan adalah seluruh siswa SMA N 1 Nguter. Jumlah sampel dalam penelitian ini jumlah sampel dibatasi sejumlah 4 siswa. Teknik pegumpulan data melalui penyebaran angkt tertutup dengan rating scale, diuji melalui uji validitas dengan teknik korelasi product moment. Uji reliabilitas dengan dengan rumus alpha. Uji hipotesis menggunakan rumus wilcoxon match pairs test. Karena dalam penelitian ini digunakan untuk menguji signifikasi hipotesis komparatif 2 sampel yang berkorelasi dan datanya berbentuk ordinal dan sampelnya tidak normal ( kurang dari 30). Analisis data menggunakan analisis deskripif dari hasil persentase tingkat pre test dan post tes yang diperbandingkan.

\section{Hasil dan pembahasan}

Berdasarkan hasil pre tes diketahui bahwa dari 50 siswa terdapat 14 siswa yang memiliki kenakalan remaja dalam tingkat sedang dan 36 siswa masuk kriteria rendah. Bila diprosentase maka $28 \%$ kenakalan siswa pada kategori sedang dan $72 \%$ masuk dalam kriteria rendah. Penelitian ini memprioritaskan kepada 4 siswa yang memiliki tingkat kenakalan remaja yang tertinggi, dikarenakan waktu untuk memberikan perlakuan dengan layanan konseling individual dengan beberapa kali pertemuan. Hasil pre test dapat diketahui kondisi kenakalan remaja pada tiap sub variable.

\begin{tabular}{|c|c|c|c|}
\hline No & Indikator & Persentase (\%) & Kriteria \\
\hline 1 & Perilaku amoral & 63,34 & Sedang \\
\hline 2 & Perilaku asosial & 60,81 & Sedang \\
\hline 3 & Pelanggaran hukum & 47,50 & Sedang \\
\hline \multicolumn{2}{|c|}{ Rata-rata } & 57,21 & Sedang \\
\hline
\end{tabular}

Dari hasil perhitungan tersebut diketahui bahwa indikator dalam angket memiliki skor yang berbeda namun dalam kriteria yang saya yaitu sedang. Rata-rata skor presentase sebesar $57,21 \%$ dengan kriteria sedang. Hal ini menunjukkkan bahwa perilaku kenakalan remaja (juneville deliquency) masih terjadi di lingkungam SMA N 1 Nguter. Kondisi responden masih sering melakukan aktivitas kenakalan remaja di sekolah. Berikut ini kondisi tiap respoden penelitian:

Tabel 2. Hasil pre test responden

\begin{tabular}{llll}
\hline No & Nama & Persentase & Kriteria \\
\hline $\mathbf{1}$ & Ds & 52,82 & Sedang \\
$\mathbf{2}$ & Ikf & 54,36 & Sedang \\
$\mathbf{3}$ & Aan & 54,36 & Sedang \\
$\mathbf{4}$ & Ap & 55,38 & Sedang \\
Rata-rata & 54,23 & Sedang \\
\hline
\end{tabular}


Tabel 2. Menunjukkan bahwa responden memiliki kenakalan remaja dalam kriteria sedang, dengan nilai persentase yang beragam. Meskipun dalam kriteria sedang, kenakalan remaja perlu diberikan upaya intervensi agar tidak berkelanjutan dan mengarah kepada tindakan kriminal dan pelanggaran hukum.

Kondisi kenakalan remaja setelah diberikan layanan konseling pendekatan behavioral mengalami perubahan di asing-masing responden. Berikut hasil perbandingan kondisi awal dan kondisi akhir kenakalan remaja:

Tabel 3. Perbandingan hasil pre test dan post test

\begin{tabular}{lllllll}
\hline \multirow{2}{*}{ No } & Nama & \multicolumn{2}{l}{ Kondisi awal } & \multicolumn{2}{l}{ Kondisi akhir } & Beda (\%) \\
\cline { 3 - 6 } & & Persentase & Kriteria & Persentase & Kriteria & \\
$\mathbf{1}$ & Ds & 52,82 & Sedang & 30,42 & Rendah & 22,4 \\
$\mathbf{2}$ & Ikf & 54,36 & Sedang & 32,46 & Rendah & 21,9 \\
$\mathbf{3}$ & Aan & 54,36 & Sedang & 34,24 & Rendah & 20,12 \\
$\mathbf{4}$ & Ap & 55,38 & Sedang & 31,20 & Rendah & 24,18 \\
Rata-rata & 54,23 & Sedang & 32,08 & Rendah & 22,15 \\
\hline
\end{tabular}

Tabel 3. Menunjukkan bahwa kenakalan remaja mengalami penurunan prosentase setelah diberikan layanan konseling pendekatan behavioral. Rata-rata penurunan sebesar 22,15 dan seluruh responden memiliki kriteria rendah setelah diberikan treatment.

Deksripsi umum mengenai responden terkait dengan kenakalan remaja yang dilakukan yaitu kebiasaan membolos, merokok, merusak barang milik teman, terlibat perkelahian antar siswa, mnegkonsumsi minuman keras, dan kebiasaan menghabiskan waktu keluar rumah dengan teman sampai larut malam. Responden sebagian besar melakukan tindakan kenakalan remaja secara berkelompok atau bersama-sama. Hal ini sesuai dengan karakter masa remaja yaitu belum mampu mengontrol perilakunya dan cenderung bersifat impulsif, dan ingin mennjukkan eksistesinya dengan cara-cara yang kurang tepat.

Latar belakang penyebab kenakalan remaja yang dilakukan oleh responden bervariasi, misalnya, ds melakukan tindakan kenakalan remaja merusak barang milik teman dan terlibat perselisihan disebabkan karena perilaku impulsif dan kurang perhatian dari orang tua. Ds memiliki orang tua yang berprofesi sebagai pedagang di ibukota Jakarta, dia dirumah bersama saudara dan kakek serta nenek. Sedangkan IKF sering melakukan kebiasaan merokok dan terlibat perkelahian antar siswa dilatar belakangi karena lingkungan sekitarnya yang kurang memberikan contoh perilaku yang tepat. Sementara aan sering membolos secara berurutan dalam satu periode waktu, misalnya dalam satu minggu mengaku pernah membolos selama 5 hari berurutan tanpa keterangan. Responden pernah mengakui bahwa kegiatan yang dilakukan saat membolos yaitu bermain game online dan berjalan-jalan ke luar kota menggunakan kendaraan sendiri padahal belum memiliki surat ijin mengemudi. Sedangkan ap sering membolos, merokok, dan sering ke luar rumah larut malam dal tersebut dilatar belakangi oleh perhatian orang tua yang kurang, karena orang tua sibuk bekerja dan lokasi kerja orang tua yang jauh sehingga perilaku anak tidak terkontrol.

Tahap assesment memberikan upaya untuk membina hubungan baik dengan responden dan membicarakan asal mula munculnya permasalahan. Mengidentifikasi permasalahan dan menyadarkan bahwa responden pernah melakukan tindakan kenakalan remaja. Langkah berikutnya adalah goal setting, informasi yang didapatkan dari tahap asessment kemudian dianalisis dan digunakan sebagai landasan untuk menyusun tujuan yang ingin dicapai dalam kegiatan konseling. Tujuan dalam kegiatan konseling tentunya untuk mengurangi tindak kenakalan remaja, dan konselor berkomitmen untuk membantu responden keluar dari permasalahannya. Tahap technique implementation, yaitu menentukan strategi 
yang digunakan untuk mencapai tujuan atau perubahan tingkah laku. Peneliti memberikan lembar kontrak perilaku kepada responden agar responden juga memiliki komitmen bersama untuk merubah atau mengurangi tindak kenakalan remaja. Tahap evaluasi, peneliti mencoba untuk menilai perkembangan permasalahan responden. Respoden diberikan kesempatan untuk mencoba merubah perilakunya dan bertanggung jawab atas keputusan yang diambilnya.

Hal tersebut menunjukkan bahwa konseling behavioral mampu mengurangi kenakalan remaja sesuai dengan hasil tahap evaluasi. Berdasarkan karakteristik konseling behavioral, menurut corey konseling behavioral memiliki karakter yang memusatkan perhatian kepada perilaku yang nampak dan spesifik, cermat dalam merumuskan tujuan konseling, langkah konseling yang spesifik terhadap masalah, dan evaluasi yang obyektif dari hasil konseling(Corey, 2013b). Bentuk kenakalan remaja yang dilakukan oleh responden merupakan masalah perlaku yang nampak atau spesifik dan bisa diamati. Peneliti juga mencoba untuk merumuskan tujuan serta strategi untuk merubah perilaku kenakalan remaja.

Keberhasilan penurunan intensitas tindak kenakalan remaja juga didukung dengan karakter responden yang menyadari bahwa dirinya memiliki kebiasaan yang kurang adaptif dan tidak sesuai dengan harapan masyarakat. Kesadaran responden dan orientasi untuk mampu menyelesaikan permasalahan menjadi modal yang sangat berharga bagi responden untuk mampu merubah perilakunya menjadi lebih adaptif.

Tugas perkembangan remaja menurut havighurst diantaranya yaitu mengharapkan dan mencapai perilaku sosial yang bertanggung jawab baik sebagai pria maupun wanita dan memperoleh perangkat nilai dan sistem etika sebagai pegangan berperilaku (Hurlock, 2002). Penurunan intensitas perilaku kenakalan remaja didorong dengan pengondisian lingkungan sekolah dan rumah yang mampu memberikan contoh siswa dalam berperilaku sesuai dengan norma di masyarakat. Kenakalan remaja sebagai bentuk siswa mengeksplorasi kemampuan dalam memerankan sesuai gender dan mencari identitas diri dengan cara mengidentifikasi perilaku di sekitarnya. Penyesuaian perilaku remaja memerlukan proses untuk memperoleh perangkat nilai yang diyakini oleh masyarakat.

Kenakalan remaja terjadi disebabkan oleh beberapa faktor diantaranya kondisi keluarga yang broken home, kurang perhatian dan kasih sayang orang tua, status sosial ekonomi orang tua rendah, kondisi keluarga yang tidak tepat(Dariyo, 2004). Secara keseluruhan dapat diinterpretasikan bahwa tindak kenakalan remaja diawali dengan tidak terpenuhinya kebutuhan psikologis anak saat berada di lingkungan keluarga. Kondisi keluarga sangat berperan bagi perilaku anak, keluarga yang kondusif dan komunikatif antar anggota keluarga memberikan kenyamanan bagi anak untuk mengidentifikasi perilaku yang sesuai dan sebaliknya. Namun bukan berarti kenakalan remaja hanya ditentukan faktor keluarga saja, melainkan lingkungan sekolah dan pergaulan siswa juga berperan mempengaruhi perilaku.

Kesesuaian teknik pendekatan konseling dengan permasalahan siswa dapat memberikan pelayanan konseling lebih efektif dan efisien. Karena tiap pendekatan konseling memiliki karakteristik yang berbeda-beda, oleh sebab itu perlu memperhatikan keunggulan pendekatan dan disesuaikan dengan permasalahan siswa. Dalam peelitian ini pendekatan behavioral lebih menekankan pada perilaku yang spesifik dan nampak, maka sesuai dengan bentuk kenakalan remaja yang dapat diamati dan diberikan perubahan perilaku yang lebih sesuai.

\section{Simpulan dan Saran}

Berdasarkan hasil perhitungan perbandingan skor pretest dan posttest, rata-rata responden mengalami penurunan kenakalan remaja sebesar $22,15 \%$. Hal ini membuktikan bahwa konseling behavioral dapat mengurangi tingkat kenakalan remaja. Sedangkan uji 
wilcoxon diperoleh $\mathrm{z}$ hitung sebesar -1.82 , karena nilai ini adalah nilai mutlak sehingga tanda negatif tidak diperhitungkan. Sehingga nilai z hitung menjadi 1.82 , selanjutnya nilai z hitung ini dibandingkan dengan nilai $\mathrm{z}$ tabel dengan taraf kesalahan 0.05. Nilai $\mathrm{z}$ tabel dengan taraf kesalahan 0.05 adalah sebesar 0 perbandingan $\mathrm{z}$ hitung dengan $\mathrm{z}$ tabel adalah 1.82 lebih besar dari 0 maka $\mathrm{z}$ hitung lebih besar dari $\mathrm{z}$ tabel. Oleh sebab itu hipotesis diterima. Simpulan penelitian ini perilaku (juneville deliquency) kenakalan remaja SMA N 1 Nguter dapat dikurangi dengan konseling pendekatan behavioral.

Saran bagi peneliti selanjutnya, yaitu untuk lebih menspesifikkan perilaku bentuk kenakalan remaja. Agar perilaku lebih spesifik dan sesuai dengan fenomena di sekolah dan mengikuti perkembangan permasalahan remaja saat ini.

\section{Daftar Pustaka}

Corey, G. (2013a). Teori dan Praktek. Konseling dan Psikoterapi. Bandung: Refika Aditama.

Corey, G. (2013b). Theory and practice of counseling and psychotherapy. Theory and Practice of Counseling and Psychotherapy 5th Ed. https://doi.org/10.1016/00223999(94)90123-6

Dariyo, A. (2004). Psikologi perkembangan remaja. Bogor: Ghalia Indonesia.

Hurlock, E. B. (2002). Psikologi Perkembangan: Suatu Pendekatan Sepanjang Rentang Kehidupan. Jakarta: Erlangga.

Kartono, K. (1992). Patologi sosial 2 kenakalan remaja. Jakarta, Rajawali Pers.

Latipun. (2014). Psikologi Konseling. Malang: UPT. Penerbit UMM.

Santrock, J. W. (2002). Life span development: Perkembangan masa hidup. Jakarta: Erlangga, 31 .

Sumiati, D., Nurhaeni, H., \& Aryani, R. (2009). Kesehatan Jiwa Remaja dan Konseling. Jakarta: Trans Info Media, 88-92.

Winkel, W. S., \& Hastuti, M. M. S. (2005). Bimbingan dan konseling di institusi pendidikan. Media Abadi.

Yusuf, S. (2016). Psikologi Perkembangan. Bandung: Rineka Cipta. 
